\title{
Using Anti-SARS-CoV-2 IgG and IgM Antibodies to Detect Outpatient Cases with Olfactory and Taste Disorders Suspected as Mild Form of COVID-19: a Retrospective Survey
}

\author{
Mohammad Hosein Taziki Balajelini ${ }^{1}$ (D) $\cdot$ Mohammad Ali Vakili $^{2}$ (D) Mohsen Saeidi $^{3}$ (D) Alijan Tabarraei $^{4}$ (D) \\ Seyed Mehran Hosseini ${ }^{5}$ (D)
}

Accepted: 27 October 2020 / Published online: 3 November 2020

(C) Springer Nature Switzerland AG 2020

\begin{abstract}
Many patients with olfactory disorders were referred during the COVID-19 pandemic in 2020. The aim of this study was to detect outpatient cases with olfactory and taste disorders suspected to mild form of COVID-19 disease in Gorgan city in the north of Iran retrospectively. This study was performed on patients who had the complaints of olfactory disorders during 03/01/2020 to 04/01/2020. They also had the mild symptoms of upper respiratory tract infection. The control group included patients who had similar symptoms during this period but did not report olfactory or taste disturbances. Due to the limitations of serologic kits, this study was performed 2-3 months after the onset of symptoms. The number of patients and controls was 72 and 36 respectively. The range and the mean \pm SD of patient's age were 21-63 and $39.82 \pm 9.82$ years. In both groups, $44.44 \%$ were male and $55.56 \%$ were female. The time interval between the onset of symptoms and the serologic tests in both groups was $91.11 \pm 16.20$ days. In the cases and controls, the $\operatorname{IgG}$ titer was positive in $44.4 \%$ and $22.2 \%$ and the $\operatorname{IgM}$ titer was positive in $5.6 \%$ and $8.3 \%$ respectively. IgG antibody titers were higher in cases than in the control group $(P=0.024)$. There was no correlation among antibody titers and the severity of olfactory disturbances, the gender, and the age. The high COVID-19 IgG antibody titer in patients with olfactory disorder during the pandemic can probably be considered as a warning complaint of COVID-19 and may be used for isolation plans.
\end{abstract}

Keywords COVID-19 $\cdot \operatorname{IgG} \cdot \operatorname{IgM} \cdot$ Olfactory $\cdot$ Taste $\cdot$ Anosmia

This article is part of the Topical Collection on COVID-19

This work was done in the Golestan University of Medical Sciences.

Seyed Mehran Hosseini

hosseini@goums.ac.ir

1 Department of Surgery, School of Medicine, Golestan University of Medical Sciences, Gorgan, Golestan, Iran

2 Department of Family and Community Medicine, School of Medicine, Golestan University of Medical Sciences, Gorgan, Iran

3 Department of Immunology, School of Medicine, Golestan University of Medical Sciences, Gorgan, Golestan, Iran

4 Department of Microbiology, School of Medicine, Infectious Diseases Research Center, Golestan University of Medical Sciences, Gorgan, Golestan, Iran

5 Department of Physiology, Neuroscience Research Center, School of Medicine, Golestan University of Medical Sciences, Shastkola, Gorgan, Golestan 4934174515, Iran

\section{Introduction}

Three groups of pathologies can cause olfactory disturbances, including chronic sinonasal disease, stroke, and viral infections of the upper respiratory tract [1]. Acute anosmia or hyposmia is stressful [2]. The olfaction has an important relationship with taste buds. Patients with hyposmia and anosmia usually have gustatory disorders [3]. Olfactory disorders have seasonal prevalence and its rate in men and women are not the same [4-6]. Many viruses have been identified as causing the upper respiratory tract infection [7]. Some viruses have also been isolated from the nasal secretions of patients with postviral olfactory disorders, P.V.O.D. [8]. There have been various reports about the olfactory and taste disturbances caused by viruses [9]. Despite the prevalence of viral diseases in certain seasons of the year, the number of patients with olfactory and taste disorders is limited. During the COVID-19 pandemic, which involved a large number of patients with upper 
respiratory tract infections, the number of cases with olfactory and taste disorders increased unexpectedly and reinforced the hypothesis that coronavirus may be the cause of the disorder $[2,10]$. So far, many types of coronaviruses have been identified. They cause a wide range of respiratory infections in humans from common colds to Middle East respiratory syndrome (MERS) and severe acute respiratory syndrome (SARS). The COVID-19 virus has unpredictable outbreaks and symptoms, and in addition to the symptoms of the upper respiratory tract, some of its unknown manifestations are still growingly clarified by further research. The reported prevalence for olfactory and taste disorders in COVID-19 is very different and varies from 5 to $68 \%$ [11-14]. Real-time PCR is the most reliable laboratory diagnosis of COVID-19. In this method, nasopharyngeal secretions are sampled with a swab. Real-time PCR is usually performed in acute and early phases of the disease and need the presence of viral shedding [15-17]. In terms of serological response, initially the IgM antibody is predominant. However, its titer is low and its seroconversion is short. The IgG response is delayed but has higher titer and it will remain stable in the serum for longer period. Therefore, a high IgG titer may be an indicator of previous infection [18]. Coronavirus can be rapidly transmitted in the community due to its very high transmission power as well as false negative results of real-time PCR tests in acute phase [15]. Exclusive testing may not be possible due to some limitations. Therefore, symptoms that are more suspicious for COVID-19 infection may potentially be useful for isolation advices. One of the symptoms that is more clear and understandable to the patient is olfactory and taste disorders. Therefore, this study was performed to evaluate the COVID$19 \mathrm{IgM}$ and $\operatorname{IgG}$ titers in patients with olfactory and taste disorders at the peak of pandemic in Gorgan city in the north of Iran during March and April 2020.

\section{Material and Methods}

This cross-sectional study was performed on patients who referred to the clinic for olfactory and taste disorders in the Gorgan city in the north of Iran from 1/03/2020 to 04/1/2020. They also had manifestations of upper respiratory tract infection. The study protocol was confirmed by the research council of Golestan University of Medical Sciences. The ethic number was IR.GOUMS.REC.1399.032. Because all patients had no occupational or other gains, we did not use additional tests for evaluation of olfactory and taste disorders and the classification of olfactory and taste disorders to complete or partial deficits types was done according to self-reporting [19]. These patients were examined by an ENT specialist and those with nasal obstructive lesions or with previous history of olfactory disorders, as well as those who had tumor or polypoid lesions were excluded from the study. The study data included age, sex, other symptoms of upper respiratory tract infection, the time interval from the onset of the disease to the onset of olfactory and taste disorders, their severity (complete or partial loss of smell and taste), time interval to serologic test, and the titer of COVID-19 IgM and IgG. Due to the high volume of hospitalized patients and the limitation of laboratory facilities during the pandemic, including real-time PCR tests, it was not done for all patients. The production of commercially available COVID-19 IgG and IgM kits was 2-3 months after the peak of pandemic in Gorgan. There was several week time-lag between onset of symptoms and serologic tests. The serological test was performed by the PISHTAZTEB ELISA kit made in Iran. This kit measured the titer of antibodies against the antigen-N of virus nucleus cover. The sensitivity and specificity of SARS-CoV-2 IgM test were $79.4 \%$ and $97.3 \%$, respectively, and for the SARS-CoV-2 IgG, it was 94.1 and $98.3 \%$, respectively. The cut-off value was determined based on the optical absorption of negative control samples and the value of cut-off index was calculated by dividing the sample optical absorption by the cut-off value. The values above 1.1 were considered positive and below 0.9 were considered negative. According to the pilot study, the initial estimate for positive cases of antibody titer was 19 and $56 \%$. The sample size was calculated in two groups based on this estimation with $95 \%$ confidence level and $90 \%$ test power and the 2 to 1 ratio for case and control groups. The calculated sample size was 72 for the case group and 36 for the control group. The two groups were matched as much as possible in terms of gender and age group. The control group included patients who had symptoms of upper respiratory tract infection during this period but did not report olfactory or taste disturbances. Patients in both groups were classified into three age clusters: under 30, 45-30, and over 45 years of age. All data were analyzed using IBM SPSS 16 statistical software and the exact Fisher's test, $\chi^{2}$, and Mann-Whitney's nonparametric test were applied. The significance level of all tests was considered 0.05. Data was expressed as mean $\pm \mathrm{SD}$.

\section{Results}

In this study, the sample size included 108 patients with upper respiratory tract infection. The case group was 72 patients with olfactory and taste disorders and the control group was 36 patients without olfactory and taste disorders. In both groups, $44.44 \%$ were male and $55.56 \%$ were female. The mean age in the cases was $39.82 \pm 9.82$ and in the controls was $39.69 \pm 8.67$ years and had no statistical difference $(P=$ $0.923)$. The age distribution of patients in age clusters was similar and did not have statistical differences. The highest number of patients in both groups was in the age cluster of 30-45 years (Table 1 ). 
Table 1 Demographic characteristics of case and control groups by gender and age clusters $(n=108)$

\begin{tabular}{|c|c|c|c|c|}
\hline Characteristics & Age (year) & Cases (72) & Controls (36) & Total (108) \\
\hline \multirow[t]{4}{*}{ Numbers $(\%)$} & $30<$ & $13(18.06)$ & $4(11.11)$ & $17(15.74)$ \\
\hline & $30-45$ & $31(43.06)$ & $24(66.67)$ & $55(50.93)$ \\
\hline & $45<$ & $28(38.89)$ & $8(22.22)$ & $36(33.33)$ \\
\hline & Total & $72(67)$ & $36(33)$ & $108(100)$ \\
\hline \multirow[t]{4}{*}{ Women:men (ratio) } & $30<$ & $8: 5(1.6)$ & $2: 2(1)$ & $10 .: 7(1.43)$ \\
\hline & $30-45$ & $20: 11(1.82)$ & $14: 10(1.4)$ & $34: 21(1.62)$ \\
\hline & $45<$ & $12: 16(0.75)$ & $4: 4(1)$ & $16: 20(0.8)$ \\
\hline & Total & $40: 32(1.25)$ & $20: 16(1.25)$ & $60: 48(1.25)$ \\
\hline \multirow[t]{4}{*}{ Mean \pm SD of age (years) } & $30<$ & $25.54 \pm 2.47$ & $24.25 \pm 1.71$ & $25.24 \pm 2.33$ \\
\hline & $30-45$ & $36.45 \pm 4.41$ & $38.21 \pm 4.10$ & $37.22 \pm 4.33$ \\
\hline & $45<$ & $50.36 \pm 4.92$ & $51.87 \pm 4.85$ & $50.69 \pm 4.87$ \\
\hline & Total & $39.82 \pm 9.82$ & $39.69 \pm 8.67$ & $39.82 \pm 9.75$ \\
\hline
\end{tabular}

The distribution of the patient's olfactory and taste disorders according to the severity of the disorder, age clusters, and gender is shown in Table 2.

The time interval between the onset of general symptoms and the onset of olfactory and taste disturbances in the case group was 0-10 days. Also, the mean of the time interval between the onset of olfactory and taste disturbances until the serologic test was $91.11 \pm 16.20$ days. The rate of IgMpositive antibody test in the case group was $5.6 \%$ and in the control group was $8.3 \%$ and according to the exact Fisher test, had no statistical difference $(P=0.429)$. The rate of $\mathrm{IgG}-$ positive antibody test was $44.4 \%$ in the case group and
$22.2 \%$ in the control group and had statistical difference $(P=0.024)$. In both groups, the percentage of positive IgG and $\operatorname{IgM}$ antibody tests in terms of gender distribution had no statistical difference (Table 3).

The mean of IgM antibody titer in the case and control groups was $0.53 \pm 1.87$ and $0.34 \pm 0.54$, respectively. Due to the lack of normality assumption and according to the result of Mann-Whitney's test, they had no statistical difference $(P=$ 0.69 ). The mean of $\operatorname{IgG}$ antibody titer in the case and control groups was $2.95 \pm 4.84$ and $0.93 \pm 2.17$, respectively. Due to the lack of normality assumption and according to the result of Mann-Whitney's test, they had statistical difference $(P=$

Table 2 Distribution of olfactory and taste disorders in patients in the case group according to the severity of the disorder, age clusters, and gender $(n=$ 72)

\begin{tabular}{|c|c|c|c|c|}
\hline Type of olfactory and taste disorders & Age (year) & $\begin{array}{l}\text { Woman } \\
\text { Number (\%) }\end{array}$ & $\begin{array}{l}\text { Man } \\
\text { Number (\%) }\end{array}$ & $\begin{array}{l}\text { Total } \\
\text { Number (\%) }\end{array}$ \\
\hline \multirow[t]{4}{*}{ Complete lack of smell } & $30<$ & $7(20.0)$ & $5(29.4)$ & $12(23.1)$ \\
\hline & $30-45$ & $19(54.3)$ & $6(35.3)$ & $25(48.1)$ \\
\hline & $45<$ & $9(25.7)$ & $6(35.3)$ & $15(28.8)$ \\
\hline & Total & $35(67.31)$ & $17(32.69)$ & $52(100)$ \\
\hline \multirow[t]{4}{*}{ Relative reduction of olfaction } & $30<$ & $1(20)$ & $0(0)$ & $1(5)$ \\
\hline & $30-45$ & $1(20)$ & $5(33.3)$ & $6(30)$ \\
\hline & $45<$ & $3(60)$ & $10(67.7)$ & $13(65)$ \\
\hline & Total & $5(25)$ & $15(75)$ & $20(100)$ \\
\hline \multirow[t]{4}{*}{ Complete lack of taste } & $30<$ & $7(20.6)$ & $5(29.4)$ & $12(23.5)$ \\
\hline & $30-45$ & $19(55.9)$ & $5(29.4)$ & $24(47.1)$ \\
\hline & $45<$ & $8(23.5)$ & $7(41.2)$ & $15(29.4)$ \\
\hline & Total & $34(66.7)$ & $12(33.3)$ & $51(100)$ \\
\hline \multirow[t]{4}{*}{ Relative decrease in taste } & $30<$ & $1(16.7)$ & $0(0)$ & $1(4.8)$ \\
\hline & $30-45$ & $1(16.7)$ & $6(40)$ & $7(33.3)$ \\
\hline & $45<$ & $4(66.7)$ & $9(60)$ & $13(61.9)$ \\
\hline & Total & $6(28.6)$ & $15(71.4)$ & $21(100)$ \\
\hline
\end{tabular}


Table 3 Frequency distribution of antibody titers in the case and control groups by gender $(n=108)$

\begin{tabular}{|c|c|c|c|c|c|c|c|}
\hline & \multicolumn{3}{|l|}{ Cases (72) } & \multicolumn{3}{|l|}{ Controls (36) } & \multirow[t]{2}{*}{$P$ value } \\
\hline & $\begin{array}{l}\text { Women } \\
\text { Number (\%) }\end{array}$ & $\begin{array}{l}\text { Men } \\
\text { Number (\%) }\end{array}$ & $\begin{array}{l}\text { Total } \\
\text { Number }(\%)\end{array}$ & $\begin{array}{l}\text { Women } \\
\text { Number (\%) }\end{array}$ & $\begin{array}{l}\text { Men } \\
\text { Number (\%) }\end{array}$ & $\begin{array}{l}\text { Total } \\
\text { Number }(\%)\end{array}$ & \\
\hline Positive cases of IgM-number (\%) & $2(5)$ & $2(6.3)$ & $4(5.6)$ & $3(15)$ & $0(0)$ & $3(8.3)$ & 0.429 \\
\hline Negative cases of $\operatorname{IgM}-$ number $(\%)$ & $38(95)$ & $30(93.8)$ & $68(94.4)$ & $17(85)$ & $16(100)$ & $33(91.7)$ & 0.201 \\
\hline Positive cases of IgG-number (\%) & $17(42.5)$ & $15(46.09)$ & $32(44.4)$ & $5(25)$ & $3(18.8)$ & $8(22.2)$ & 0.024 \\
\hline Negative cases of $\mathrm{IgG}-$ number $(\%)$ & $23(57.5)$ & $17(53.1)$ & $40(55.6)$ & $15(75)$ & $13(81.3)$ & $28(77.8)$ & 0.185 \\
\hline
\end{tabular}

0.029). The number of positive $\operatorname{IgM}$ and $\mathrm{IgG}$ antibody tests and the mean of them according to the severity of olfactory and taste disorders are presented in Table 4.

The severity of olfactory and taste disturbances and the complete or partial recovery of the disorder according to the gender are presented in Table 5.

There was not any significant relationship between severity of olfactory and taste disturbances, the time interval until the antibody test, the rate of recovery of olfactory and taste disorders during this period, and the $\operatorname{IgG}$ and IgM antibody titers (Table 6).

\section{Discussion}

This study was conducted at the peak of the corona pandemic period between 03/1/2020 and 04/20/120 in Gorgan city in the north of Iran. Seventy-two patients with olfactory and taste disorders were examined. $55.5 \%$ of them were women and $44.5 \%$ of them were men. The women were reported more likely to develop olfactory dysfunction $[5,8]$. Tian.j et al. reported a higher rate of female-to-male ratio of viral olfactory disorders [4]. In our study, the range of age was between 21 and 63 years and the mean of age was $39.82 \pm 9.82$ years. Doty et al. reported the olfactory disorder in older age [6]. de Haro-Licer et al. reported the maximum prevalence at age 50 [5]. Quint et al. reported that the maximum prevalence of olfactory impairment had occurred at 50-year-old age [8]. Tiun.j et al. also stated that older people were more susceptible and had worse prognosis [4]. Our results are different from the results of the above mentioned studies. They reported the olfactory disorders at higher ages. One reason for this difference may be caused by sampling method. We used an outpatient setting for random selection of cases and they were usually in

Table 4 Number of positive IgM and IgG antibody titers of case and control groups and the mean and standard deviations of them according to the severity of olfactory and taste disorders $(n=108)$

\begin{tabular}{|c|c|c|c|c|c|c|c|c|c|c|}
\hline \multicolumn{2}{|c|}{ Study groups } & \multirow{3}{*}{$\begin{array}{l}\text { Age } \\
\text { (year) }\end{array}$} & \multicolumn{4}{|l|}{ IgM } & \multicolumn{4}{|l|}{$\operatorname{IgG}$} \\
\hline & & & \multicolumn{2}{|l|}{ Women } & \multicolumn{2}{|l|}{ Men } & \multicolumn{2}{|l|}{ Women } & \multicolumn{2}{|l|}{ Men } \\
\hline & & & $\begin{array}{l}\text { Number } \\
(\%)\end{array}$ & $\begin{array}{l}\text { Mean } \pm \\
\text { SD }\end{array}$ & $\begin{array}{l}\text { Number } \\
(\%)\end{array}$ & $\begin{array}{l}\text { Mean } \pm \\
\text { SD }\end{array}$ & $\begin{array}{l}\text { Number } \\
(\%)\end{array}$ & $\begin{array}{l}\text { Mean } \pm \\
\text { SD }\end{array}$ & $\begin{array}{l}\text { Number } \\
(\%)\end{array}$ & $\begin{array}{l}\text { Mean } \pm \\
\text { SD }\end{array}$ \\
\hline \multirow[t]{16}{*}{ Cases (72) } & \multirow[t]{4}{*}{ Complete lack of smell } & $30<$ & $7(20)$ & $0.274(0.262)$ & $5(29.4)$ & $0.266(0.264)$ & $7(20)$ & $1.434(1.328)$ & $5(29.4)$ & $0.756(1.01)$ \\
\hline & & $30-45$ & $19(54.3)$ & $1.16(3.568)$ & $6(35.3)$ & $0.422(0.505)$ & $19(54.3)$ & $1.405(2.678)$ & $6(35.3)$ & $3.232(5.462)$ \\
\hline & & $45<$ & $9(25.7)$ & $0.229(0.238)$ & $6(35.3)$ & $0.272(0.378)$ & $9(25.7)$ & $2.973(3.864)$ & $6(35.3)$ & $8.183(7.261)$ \\
\hline & & Total & $35(100)$ & $0.743(2.641)$ & $17(100)$ & $0.323(0.384)$ & $35(100)$ & $1.814(2.846)$ & $17(100)$ & $4.251(6.005)$ \\
\hline & \multirow{4}{*}{$\begin{array}{l}\text { Relative reduction of } \\
\text { olfaction }\end{array}$} & $30<$ & $1(20)$ & $0.46(-)$ & $0(0)$ & - & $1(20)$ & $0.14(-)$ & $0(0)$ & - \\
\hline & & $30-45$ & $1(20)$ & $0.24(-)$ & $5(33.3)$ & $0.11(0.113)$ & $1(20)$ & $0.51(-)$ & $5(33.3)$ & $0.436(0.578)$ \\
\hline & & $45<$ & $3(60)$ & $0.973(1.275)$ & $10(66.7)$ & $0.238(0.3)$ & $3(60)$ & $6.647(6.644)$ & $10(66.7)$ & $6.009(7.445)$ \\
\hline & & Total & $5(100)$ & $0.724(0.967)$ & $15(100)$ & $0.195(0.265)$ & $5(100)$ & $2.918(5.263)$ & $15(100)$ & $3.843(6.567)$ \\
\hline & \multirow{4}{*}{ Complete lack of taste } & $30<$ & $7(20.6)$ & $0.274(0.262)$ & $5(29.4)$ & $0.266(0.264)$ & $7(20.6)$ & $1.434(1.328)$ & $5(29.4)$ & $0.756(1.01)$ \\
\hline & & $30-45$ & $19(55.9)$ & $1.173(3.564)$ & $5(29.4)$ & $0.504(0.518)$ & $19(55.9)$ & $1.411(2.676)$ & $5(29.4)$ & $3.878(5.845)$ \\
\hline & & $45<$ & $8(23.5)$ & $0.236(0.253)$ & $7(41.2)$ & $0.327(0.375)$ & $8(23.5)$ & $3.345(3.955)$ & $7(41.2)$ & $9.723(7.78)$ \\
\hline & & Total & $34(100)$ & $0.767(2.678)$ & $17(100)$ & $0.361(0.383)$ & $34(100)$ & $1.871(2.869)$ & $17(100)$ & $5.366(6.865)$ \\
\hline & \multirow[t]{4}{*}{ Relative decrease in taste } & $30<$ & $1(16.7)$ & $0.46(-)$ & $0(0)$ & - & $1(16.7)$ & $0.14(-)$ & $0(0)$ & - \\
\hline & & $30-45$ & $1(16.7)$ & $0.00(-)$ & $6(40)$ & $0.093(0.109)$ & $1(16.7)$ & $0.39(-)$ & $6(40)$ & $0.363(0.547)$ \\
\hline & & $45<$ & $4(66.6)$ & $0.772(1.116)$ & $9(60)$ & $0.191(0.277)$ & $4(66.6)$ & $3.485(5.902)$ & $9(60)$ & $4.57(6.25)$ \\
\hline & & Total & $6(100)$ & $0.925(0.92)$ & $15(100)$ & $0.152(0.225)$ & $6(100)$ & $2.412(4.865)$ & $15(100)$ & $2.887(5.194)$ \\
\hline \multirow{4}{*}{\multicolumn{2}{|c|}{ Control (36) }} & $30<$ & $2(10)$ & $0.14(0.057)$ & $2(12.5)$ & $0.02(0.014)$ & $2(10)$ & $0.095(0.078)$ & $2(12.5)$ & $0.005(0.007)$ \\
\hline & & $30-45$ & $14(70)$ & $0.306(0.297)$ & $10(62.5)$ & $0.188(0.202)$ & $14(70)$ & $0.679(1.015)$ & $10(62.5)$ & $0.52(0.814)$ \\
\hline & & $45<$ & $4(20)$ & $1.155(1.316)$ & $4(25)$ & $0.32(0.399)$ & $4(20)$ & $1.342(1.482)$ & $4(25)$ & $3.325(6.026)$ \\
\hline & & Total & $20(100)$ & $0.459(0.681)$ & $16(100)$ & $0.2(0.254)$ & $20(100)$ & $0.753(1.084)$ & $16(100)$ & $1.157(3.059)$ \\
\hline
\end{tabular}


Table 5 Distribution of severity of olfactory and taste disorders and the rate of complete or partial recovery of the disorder by gender $(n=72)$

\begin{tabular}{|c|c|c|c|c|c|}
\hline & & $\begin{array}{l}\text { Women } \\
\text { Number (\%) }\end{array}$ & $\begin{array}{l}\text { Men } \\
\text { Number (\%) }\end{array}$ & $\begin{array}{l}\text { Total } \\
\text { Number (\%) }\end{array}$ & $P$ value \\
\hline The severity of the olfactory disorder & $\begin{array}{l}\text { Complete absence } \\
\text { Relative decrease }\end{array}$ & $\begin{array}{l}35(87.5) \\
5(12.5)\end{array}$ & $\begin{array}{l}17(53.1) \\
15(46.9)\end{array}$ & $\begin{array}{l}52(72.22) \\
20(27.78)\end{array}$ & 0.001 \\
\hline The severity of the taste disorder & $\begin{array}{l}\text { Complete absence } \\
\text { Relative decrease }\end{array}$ & $\begin{array}{l}34(85) \\
6(15)\end{array}$ & $\begin{array}{l}17(53.1) \\
15(46.9)\end{array}$ & $\begin{array}{l}51(70.63) \\
21(20.17)\end{array}$ & 0.003 \\
\hline Recovery of smell disorder & $\begin{array}{l}\text { Complete } \\
\text { Relative }\end{array}$ & $\begin{array}{l}26(65) \\
10(25)\end{array}$ & $\begin{array}{l}26(81.3) \\
4(12.5)\end{array}$ & $\begin{array}{l}52(72.22) \\
14(19.44)\end{array}$ & 0.304 \\
\hline Recovery of taste disorders & $\begin{array}{l}\text { Complete } \\
\text { Relative }\end{array}$ & $\begin{array}{l}28(70) \\
8(20)\end{array}$ & $\begin{array}{l}27(84.4) \\
3(9.4)\end{array}$ & $\begin{array}{l}55(76.39) \\
11(15.28)\end{array}$ & \multirow[t]{2}{*}{0.35} \\
\hline & No recovery & $4(10)$ & $2(6.3)$ & $6(8.33)$ & \\
\hline
\end{tabular}

a better general condition. However, the rate of hospital admission is generally higher in older peoples. In our study, the patients were affected between $03 / 20 / 20$ and 20/04/20, and after this date, the prevalence of the COVID-19 had dropped to lower level. One study found a high prevalence of olfactory disturbances in the May and June months and lower in the winter season [20]. de Haro-Licer et al. reported a more common olfactory disturbance in spring and summer [5]. The time window of olfactory disorder in our study is different from other studies. This is due to time of COVID-19 pandemic in Gorgan city in the north of Iran, which peaked from 03/1/2020 to $04 / 20 / 12020$. There are different reports about the serologic response and antibody tests of COVID-19. However, the associations or relationships between specific COVID-19 IgG or IgM antibodies titer with the viral load, infectivity, and immunity need more study [21-29].

Nagasawa et al. studied 26 hospitalized COVID-19 patients with pneumonia. They reported specific COVID-19 IgG or IgM antibodies seroconversion using 3 different ELISA kits and reported that the sensitivity of these antibodies was $100 \%$ after 2 weeks. They did not observe any differences in the antibodies titer or their trends between moderate and sever cases of COVID-19 disease. However, they suggested that seroprevalence can provide informative data in subacute phases of disease for planning health programs or isolation policies [31]. Our data was in favor to this suggestion and indicated that the serologic survey may be used for detection of missed cases of COVID-19 or for tracing the spread of this disease. Bentivegna et al. reported a case with complex pattern of seroconversion and seroreversion of specific COVID-19 IgG or IgM antibodies along with different RT-PCR tests that changes from positive to negative and then again to positive results. They suggest that antibodies may be effective against sever form of COVID-19 disease [31]. Our data did not show any correlation among antibody titers and the severity of olfactory disturbances, the gender, and the age. These finding were somewhat similar to result of Nagasawa et al. [30]. Markaronidis et al. reported the seroprevalence of specific COVID-19 IgG or IgM antibodies in 590 cases with olfactory or taste disorders. There were no other clinical symptoms in $40 \%$ of seropositive cases. The highest rate of seroconversion belonged to IgG and followed by both of IgG and IgM and the

Table 6 Distribution and relationship between the severity of olfactory and taste disorders, the degree of complete or partial recovery of the disorder, and the $\operatorname{IgG}$ and $\operatorname{IgM}$ antibody type in the case group $(n=72)$

\begin{tabular}{|c|c|c|c|c|c|}
\hline & & Number of patients (\%) & Mean \pm SD IgG & Mean \pm SD IgM & \\
\hline \multirow{2}{*}{$\begin{array}{l}\text { The severity of the } \\
\text { olfactory disorder }\end{array}$} & Complete absence & $52(72.22)$ & $2.611(4.248)$ & $0.606(2.177)$ & \multirow{10}{*}{$\begin{array}{l}\text { According to Mann-Whitney's } \\
\text { nonparametric test, there were no } \\
\text { significant relationships in any of } \\
\text { the subgroups. }\end{array}$} \\
\hline & Relative decrease & $20(27.78)$ & $3.843(6.157)$ & $0.327(0.548)$ & \\
\hline \multirow{2}{*}{$\begin{array}{l}\text { The severity of the taste } \\
\text { disorder }\end{array}$} & Complete absence & $51(70.83)$ & $0.632(2.195)$ & $0.632(2.195)$ & \\
\hline & Relative decrease & $21(29.17)$ & $0.278(0.537)$ & $0.278(0.537)$ & \\
\hline \multirow{3}{*}{$\begin{array}{l}\text { Recovery of the olfactory } \\
\text { disorder }\end{array}$} & Complete & $52(72.22)$ & $2.829(4.817)$ & $0.275(0.297)$ & \\
\hline & Relative & $14(19.44)$ & $3.46(5.549)$ & $1.599(4.148)$ & \\
\hline & No recovery & $6(8.33)$ & $2.845(4.187)$ & $0.232(0.241)$ & \\
\hline \multirow{3}{*}{$\begin{array}{l}\text { Recovery of the taste } \\
\text { disorders }\end{array}$} & Complete & $55(76.39)$ & $2.731(4.707)$ & $0.558(2.117)$ & \\
\hline & Relative & $11(15.28)$ & $4.122(6.003)$ & $0.542(0.741)$ & \\
\hline & No recovery & $6(8.33)$ & $2.845(4.187)$ & $0.232(0.241)$ & \\
\hline
\end{tabular}


lowest rate belonged to IgM alone [32]. We also observed a similar pattern of seroprevalence in specific COVID-19 IgG or IgM antibodies. We also observed higher rate of positive IgG and also higher level of IgG titers in patients with olfactory disorders.

In this study, the $\operatorname{IgM}$ and the $\operatorname{IgG}$ antibody tests against COVID-19 were positive in $5.6 \%$ and $44.4 \%$ of cases respectively. These rates in the control group were $8.3 \%$ and $22.2 \%$ respectively. Thus, the probability of positive $\operatorname{IgG}$ antibody titer in patients of the case group was twice as high as the control group. This may indicate the relationship between olfactory and taste disorders with coronavirus during the corona pandemic period in Gorgan. The role of the viruses in the development of olfactory and taste disorders is well known $[1,5]$. However, the type of viruses in previous mentioned studies differs from our study. These studies do not report COVID-19 but here we report the serological evidence for it. In recent studies, the prevalence of olfactory and taste disorders in patients with COVID-19 has been reported to be $85.6 \%$ and $88 \%$ respectively. In $11.8 \%$ of these cases, this disorder has been started before other symptoms [20]. These studies also reported higher prevalence of the olfactory and taste disturbances in women [6]. Another study in the UK declared that the olfactory impairment can be considered as the fourth most common sign of COVID-19 in the recent pandemic [11]. Another study in Italy reported the rate of olfactory and taste disturbance in $19.4 \%$ of COVID-19 patients, but acknowledged that this rate was falsely lower than the actual incidence because sever ill COVID-19 patients paid less attention to this symptom [13]. According to the findings of this study, if a patient present with symptoms of olfactory and taste disorders, with or without other symptoms, COVID-19 is highly suggested. This condition is important in isolating these patients during pandemics.

Our study had some limitations. They include one-point serologic assay instead of multiple interval serologic measurements and several weeks' interval between clinical and serological assessments. However, they were unavoidable due to the high prevalence of the disease and the limitation of available laboratory facilities and diagnostic kits during the peak of the disease.

\section{Conclusion}

A high percentage of patients with olfactory and taste disorders during recent COVID-19 pandemic are more likely to have this infection. The health care system should pay special attention to this symptom and plan a special screening and isolation program for them.
Acknowledgments Sincere thanks are given to all patients who participated in the study.

Authors' Contributions MHTB and SMH contributed to the design and the concept of the study. They did the literature search, clinical studies, manuscript draft preparation, and manuscript editing. MAV contributed to the data analysis and the manuscript revision. AT and MS contributed to the laboratory works and data acquisition. All authors approved the final manuscript.

Funding This work was financially supported by the grant No. 57111572 from Golestan University of Medical Sciences.

Data Availability All data are available upon request.

\section{Compliance with Ethical Standards}

Conflict of Interest The authors declare that they have no conflict of interest.

Ethics Approval The study protocol was confirmed by the research council of Golestan University of Medical Sciences. The ethic number was IR.GOUMS.REC.1399.032.

Consent to Participate All participants were informed about the study and assigned the informed consent.

Consent for Publication Not applicable.

\section{References}

1. Murphy C. Prevalence of olfactory impairment in older adults. JAMA. 2002;288:2307-12.

2. Gorzkowski V, Bevilacqua S, Charmillon A, Jankowski R, Gallet $\mathrm{P}$, Rumeau C, et al. Evolution of olfactory disorders in COVID-19 patients. Laryngoscope. 2020;130:2667-73. https://doi.org/10. 1002/lary.28957.

3. Neto FP. Anormalidades sensoriais: olfato e paladar. Int Arch Otorhinolaryngol. 2011;15:350-8.

4. Tian J. Analysis of clinical characteristics of 141 patients with postviral olfactory dysfunction. Lin Chung Er Bi Yan Hou Tou Jing Wai Ke Za Zhi. 2017;31:749-52.

5. de Haro-Licer J. Long term serious olfactory loss in colds and/or flu. Acta Otorrinolaringol Esp. 2013;64:331-8.

6. Seo BS. Treatment of postviral olfactory loss with glucocorticoids, Ginkgo biloba, and mometasone nasal spray. Arch Otolaryngol Head Neck Surg. 2009;135:1000-4.

7. Sugiura M. An epidemiological study of postviral olfactory disorder. Acta Otolaryngol Suppl. 1998;538:191-6.

8. Quint C, Temmel AF, Schickinger B, Pabinger S, Ramberger P, Hummel T. Patterns of non-conductive olfactory disorders in eastern Austria: a study of 120 patients from the Department of Otorhinolaryngology at the University of Vienna. Wien Klin Wochenschr. 2001;113(1-2):52-7.

9. Seiden AM. Postviral olfactory loss. Otolaryngologic Clinics of North America. 2004;37:1159-66.

10. Gilani S. COVID-19 and anosmia in Tehran, Iran. Med Hypotheses. 2020;141:109757.

11. Hopkins C. Presentation of new onset anosmia during the COVID19 pandemic. Rhinology. 2020;58:295-8. 
12. Yan $\mathrm{CH}$, Faraji F. Association of chemosensory dysfunction and COVID-19 in patients presenting with influenza-like symptoms. Int Forum Allergy Rhinol. 2020; https://doi.org/10.1002/alr.22579.

13. Vaira LA, Salzano G. Anosmia and ageusia: common findings in COVID-19 patients. Laryngoscope. 2020;https://doi.org/10.1002/ lary.28692.

14. Russell B, Moss C, Rigg A, et al. Anosmia and ageusia are emerging as symptoms in patients with COVID-19: what does the current evidence say? Ecancermedicalscience. 2020;14:ed98. Published 2020 Apr 3. https://doi.org/10.3332/ecancer.2020.ed98.

15. Li G. Coronavirus infections and immune responses. J Med Virol. 2020;92:424-32.

16. Prompetchara E. Immune responses in COVID-19 and potential vaccines: lessons learned from SARS and MERS epidemic. Asian Pac J Allergy Immunol. 2020;38:1-9.

17. Diao B. Reduction and functional exhaustion of $\mathrm{T}$ cells in patients with coronavirus disease 2019 [COVID-19]. Front Immunol. 2020;11:827.

18. Song YG. COVID-19, a clinical syndrome manifesting as hypersensitivity pneumonitis. Infect Chemother. 2020;52:110-2.

19. Doty RL. Development of the University of Pennsylvania Smell Identification Test: a standardized microencapsulated test of olfactory function. Physiol Behav. 1984;32:489-502.

20. Lechien JR. Olfactory and gustatory dysfunctions as a clinical presentation of mild-to-moderate forms of the coronavirus disease [COVID-19]: a multicenter European study. Eur Arch Otorhinolaryngol. 2020;277:2251-61.

21. Long QX. Antibody responses to SARS-CoV-2 in patients with COVID-19. Nat Med. 2020;26:845-8.

22. Long QX, Tang XJ. Clinical and immunological assessment of asymptomatic SARS-CoV-2 infections. Nat Med. 2020;26:1200-4.

23. Xiang F, Wang X. Antibody detection and dynamic characteristics in patients with COVID-19. Clin Infect Dis. 2020: ciaa461. https:// doi.org/10.1093/cid/ciaa461.
24. Kohmer N, Westhaus S. Clinical performance of different SARSCoV-2 IgG antibody tests. J Med Virol. 2020;92:1-5. https://doi. org/10.1002/jmv.26145.

25. Lee YL. Dynamics of anti-SARS-Cov-2 IgM and IgG antibodies among COVID-19 patients. J Inf Secur 2020: S01634453[20]30230-9.

26. Hoffman T, Nissen K. Evaluation of a COVID-19 IgM and IgG rapid test; an efficient tool for assessment of past exposure to SARS-CoV-2. Infect Ecol Epidemiol. 2020;10. https://doi.org/10. 1080/20008686.2020.1754538.

27. Suhandynata RT, Hoffman MA. Longitudinal monitoring of SARS-CoV-2 IgM and IgG seropositivity to detect COVID-19. J Appl Lab Med. 2020: jfaa079. https://doi.org/10.1093/jalm/ jfaa079.

28. Guo L, Ren L. Profiling early humoral response to diagnose novel coronavirus disease [COVID-19]. Clin Infect Dis. 2020. ciaa310. https://oi.org/10.1093/cid/ciaa310.

29. Sun B, Feng Y. Kinetics of SARS-CoV-2 specific IgM and IgG responses in COVID-19 patients. Emerg Microbes Infect. 2020;9: 940-8. https://doi.org/10.1080/22221751.2020.1762515.

30. Nagasawa M, Yamaguchi Y. Investigation of anti-SARS-CoV-2 IgG and IgM antibodies in the patients with COVID-19 by three different ELISA test kits. SN Compr Clin Med. 2020;2:1323-7. https://doi.org/10.1007/s42399-020-00409-7.

31. Bentivegna E. Sentimentale ANew IgM seroconversion and positive RT-PCR test after exposure to the virus in recovered COVID19 patient. J Med Virol. 2020. https://doi.org/10.1002/jmv.26160.

32. Makaronidis J, Mok J. Seroprevalence of SARS-CoV-2 antibodies in people with an acute loss in their sense of smell and/or taste in a community-based population in London, UK: an observational cohort study. PLoS Med. 2020;17:e1003358. https://doi.org/10.1371/ journal.pmed.1003358.

Publisher's Note Springer Nature remains neutral with regard to jurisdictional claims in published maps and institutional affiliations. 